\title{
HOLISTIC ACADEMIC SUPERVISION MODEL FOR CULTURAL ART TEACHERS OF VOCATIONAL HIGH SCHOOLS
}

\author{
Sri Ambarwangi* \\ Maman Rachman** \\ ${ }^{\square}$ Cultural Art Teacher of Vocational High School Pringapus Ungaran, Indonesia \\ *E-mail: sriambarwangi@gmail.com \\ Postgraduate Lecturer of Semarang State University, Indonesia \\ **E-mail: marachman102@yahoo.com
}

Received: April 22, 2015. Revised: May 5, 2015. Accepted: June 13, 2015

\begin{abstract}
This study is aiming at (1) describing and analyzing the current implementation of academic supervision (factual model), (2) generating and analyzing academic supervision model as needed (hypothetical model), and (3) identifying and analyzing the effectiveness of a holistic model of academic supervision (the final model). The method employed in this research was the Research and Development (R\&D) method, which was divided into three phases: a preliminary study, stage of development and evaluation stages. The data sources were the school superintendents, teachers, as well as students. Further, the data were collected by conducting interviews, questionnaires, and observations. Results showed that the current implementation of academic supervision was considered less effective. The academic supervision which is considered as appropriate for cultural art teachers is a holistic academic supervision. It involves school superintendents and cultural art teachers who are supervised, starting from the planning stage up to the follow-up stage, so that, a good relationship between them will be established. It is concluded in this study that a holistic academic supervision model is effective to enhance the professional competence of cultural art teachers.
\end{abstract}

Keywords: Academic Supervision; Holistic Supervision Model; Cultural Art Teachers

How to Cite: Ambarwangi, S., \& Rachman, M. (2015). Holistic Academic Supervision Model for Cultural Art Teachers of Vocational High Schools. Harmonia: Journal of Arts Research And Education, 15(1), 56-61. doi:http://dx.doi.org/10.15294/ harmonia.v15i1.3756

\section{INTRODUCTION}

A supervisor, in this case is a school superintendent or an educational unit superintendent, is assigned to have a full responsibility and authority to carry out the academic supervision has not met the exacademic and managerial supervision in pectation. Widodo (2007), in his research, all schools under their educational units. found that the implementation of superviThe Government through the Ministry of sion by supervisors in Indonesia is still far National Education has issued a National from the theory of supervision. The current Education Ministry Regulation Number 12 Year 2007 on Supervisory Standard for
School/ Islamic Based School which regulates the supervisory rules (Department of Education and Culture, 2012).

Supervisory activity refers to the elements of coaching. However, the current implementation of supervision still tends to be conducted as the inspection or moni- 

toring activities only. Supervision which is pecially in Semarang Regency, the supervidone by the supervisor also has not done sors use the same supervision instrument routinely and it seems only to find the fault model for every subject they supervised. of the teachers. In other words, the current Therefore, the supervisors can only assess supervision activities have not been ap- the general ability of the subject teachers propriate for the actual needs of teachers. (the administrative requirements), while

Based on the researcher's own expe- the teacher mastery of the subject is less rience during the time serving as a teach- able to be measured. The cultural arts as a er, supervision has never been done op- school subject has its own characteristics. timally. Supervision is merely a physical It requires teachers to conduct the teaching administrative procedure. It comprises the and learning process by using certain metmonitoring activity related to the compre- hods which reflect the characteristics of the hensiveness of the teachers' teaching aids subject. Thus, students can receive cultural and other administrative documents, such art materials and experiences maximumly as syllabus and lesson plan. Whereas, te- in order to achieve the learning goals as acher mastery in comprehending the sub- stated in the educational unit curriculum ject receives less attention. If a teacher does which is allowing students to appreciate, not master the material or subject they create, express, and respect humanity.

have to teach, it will never be detected. It Teaching cultural arts is not enough seems contradict to the main substance of by only giving theory or delivering lecacademic supervision which is supposed tures, but more to give chances to the to supervise the learning process including students to directly express, create, and the teacher mastery of the material. appreciate feelings and ideas. In learning

Based on researcher's own observa- art education, aesthetic experience is contion in the research field and the initial in- siderably important to form the students' terview with several Senior High School/ personality. Aesthetic experience which Vocational High School's teacher superin- forms the characteristics of the students, tendents on February, 2015, it was found creativity which establishes the students' that the current supervision model is still creative soul, as well as art appreciation general and administrative. It specifical- which forms the students' appreciation for ly examines the completion of teacher's the environment are some of the specific teaching aids and documents, while the purposes which are owned by cultural art teacher's comprehension in mastering the subject. In the end, all of the purposes lead subject based on the characteristic of the to the general aim of learning which is the cultural art subject receives less attention. educational purposes in school itself (AmA supervisor conducts the supervision barwangi, 2014, p. 39).

based on the supervisory instrument or The above things should be a conprogram that they create themselves. At cern of related parties to finally create an the time of supervision at schools, they ra- appropriate supervision model of the culrely enter the classroom and just observe tural art subject. The supervision model the learning process from outside the clas- has to comprise all aspects, including the sroom. Later, they will use the supervisory administrative and academic aspects that instrument to assess the teacher's perfor- pay more attention to the characteristics of mance. The supervisory instrument itself cultural arts. This is what researcher calis similar to every other subject, including led as holistic supervision model. Anyone cultural arts.

Each subject has different characteristics, so that, the supervision instrument needs to be created differently from one subject to another subject based on each characteristic. However, in reality, essupervises cultural art subject will do the supervision appropriately if there has been a proper supervision model with specific instruments for the cultural art subject.

The content of art and culture as mandated in government regulation num- 
ber 19 in 2005 about National Education mulated a concept of supervision as "the Standard is not only presented in one sub- assistance in the development of a better ject, since the culture itself comprises all teaching learning situation". This formuaspects of life. The cultural art education lation suggests that supervision services is given at school because of its unique role need to cover the whole teaching and learwhich could not be carried out by other ning situation, comprises: goal, material, subjects. The uniqueness lies in the pro- technique, method, teacher, student, and vision of aesthetic experience in the form an environment). The learning situations of expression, creation, and appreciation mentioned before need to be rectified and through the approaches of: "learning with improved through supervision activities. art", "learning through art", and "learning Therefore, a supervision is expected to enabout art" (Suharto, 2007, p. 211).

compass a whole aspect of education and

The educational characteristic of cul- teaching.

tural art subjects has its own uniqueness The concept of supervision cannot be that is different from other subjects. Cul- equated with inspection. While inspection tural art subject actively involves human underlines more to the power and authothoughts, senses, as well as physical skills. ritative, supervision tends to emphasize Therefore, in its supervision implemen- on the importance of friendship which is tation, a supervisor has to employ an ap- based on the provision of services and a propriate model, so that the teachers are better cooperation between teachers, beable to design a teaching and learning plan cause it is more democratic.

with the appropriate and effective methods.

Supervision which closely relates to the learning activities is usually known as

A holistic model of academic super- learning supervision. This learning supervision is expected to solve the problem vision is defined as an attempt to stimuladuring the implementation of the current te, coordinate, and guide the development academic supervision. This supervision is of teachers at school either individually expected to be able touch all aspects nee- or in groups with tolerance and effective ded by the teachers. Teachers feel the need pedagogical acts. Thus, teachers are more for the presence of a supervisor to correct capable of stimulating and guiding the and reveal their weaknesses. In the imple- development of each student in order to mentation phase of the suggested super- participate in a more democratic society vision model, a supervisor requires to ob- (Soetopo, 1982).

serve the teachers' teaching behavior. The

In line with earlier argument is Gliresults obtained are further analyzed and ckman (1981) who mentioned that acadeassessed. Later, coaching and follow-up mic supervision is a series of activity in are conducted in order to determine the helping teachers to develop their abilities next program.

Educational supervision is a formal guidance in a form of supervision and monitoring in order to fix the current educational condition in general as well as to improve the teaching and learning quality in particular. In addition, supervision is considerably needed in every implementation of educational program. As previously stated by Purwanto (1987), supervision is a planned guiding activity that is held to help teachers and school staffs to do their work more effectively.

Wiles as cited in Lola (2011) has forin managing the learning process in order to achieve the learning purposes. Therefore, the essence of academic supervision is a professional assistance given to teachers so that the teachers can increase the learning quality (Daresh, 1981). In other words, it helps teachers to increase their professional ability.

A holistic academic supervision in this study is the ability of a supervisor to comprehend a whole aspect of guidance activity for teachers, starting from the stage of planning, implementation, evaluation, as well as the follow-up. It includes 
the characteristics of cultural art subjects. ers who often supervised, otherwise, there The characteristic here is a unique part of are also teachers who rarely and never suthe cultural art subject which is only emp- pervised. Supervisors usually conduct the loyed by this subject and cannot be found supervision generally, equating cultural in other subjects, like, mathematics. This art with other subjects. They also has not is because cultural art subject has its own touched the aspects cultural art characspecific learning goal which also leads to teristics. This is understandable because the more general learning purposes.

the supervisors have different scientific

A holistic academic supervision also backgrounds with the cultural art teachers.

have to pay attention to the whole gene- Academic supervisory plan that inral aspect as in the academic supervision. cludes visitation schedule to target schools Furthermore, several specific aspects rela- yet to be disseminated to the target schools. ting to the character and cultural art lear- Socialization itself is important to synchroning goal are also included here.

\section{METHOD}

Research and Development (R\&D) is implemented as the research method in this study. R\&D method is selected since the method is usually used to produce or develop a certain product and to test the effectiveness of the product (Sugiyono, 2009, p. 407).

\section{The Research Procedure}

There are ten steps in R\&D method as stated by Borg and Gall (1989). However, in order to be more effective and efficient in its implementation, Samsudin (2009, p.92) has simplified the steps in three main steps. The three steps are applied here. First, a preliminary study which includes literature studies, field studies, and a description as well as analysis of the findings (factual model). Second, the stage of development and result, comprises the steps of: 1. The formulation of format and the product design; 2 . The development of product; 3 . Validation by experts; 4 . Evaluation and revision. Third, The limited trials; The evaluation and improvement of the final product; and Lastly, the final result of product.

\section{RESULTS AND DISCUSSION}

\section{Results}

In a preliminary study, the implementation of academic supervision is limited to certain teachers. There are teachnize the program with a program that has been created by the school. Realization schedule often does not correspond with what has been planned. Currently, visitation schedule is usually incidental.

Different results expressed by some teachers during the observation. They argue that the supervision performed is usually incidental. The important point is that all teachers are supervised. Therefore, supervision can only be conducted in the common way by monitoring or checking the teaching document administratively. Usually, the supervisor visits the school during the academic crucial moments, such as the semester examination or national examination right after the teacher certification assessment. It happens since the supervisors' educational background is different to the teachers they are supervised.

At the stage of the implementation of academic supervision, supervisors supervise the teachers based on the supervision instruments. It comprises the supervision instrument of: lesson planning, learning implementation, as well as the learning assessment. Based on the researcher's own observation in the field, the supervision is mostly conducted administratively by only checking the teaching and learning documentation, so that the instrument used in the supervision is only the lesson planning instrument. Whilst, the learning implementation instrument is rarely or sometimes never be carried out, because the supervisors never do classroom visitation.

The essence of academic supervisi- 
on is seeing the performance of teachers ried out tends not to be followed up. while they are teaching in the classroom. Results on the teacher's working Since the academic supervision is actually performance research as well as number a professional help given by supervisors of supervision which has ever received by to improve the quality of learning, so that, teachers show that the supervision which measuring the teacher's ability in teaching is carried out by supervisors are varied. is supposed to be done while observing the Results of the study on teacher feedback actual classroom teaching and learning. regarding to the implementation of su-

Another challenge in supervising pervision carried out by the school supecultural art teacher lies on the cultural art rintendents showed that the majority of teachers themselves. The teachers seems to respondents felt that the supervision had still confused on where should they bring not met the teacher's expectations. There their subject. All this time, learning has not were $60 \%$ of respondents argued that the led to the aspects or characteristics of the supervision was not conducted regularly cultural arts, so that the teachers have not and usually without a fix schedule. $80 \%$ of known the direction that will be addressed respondents felt that the supervision they by the subject yet. This will cause difficul- encounter did not fit their scientific backgties for teachers to design the appropriate round. Furthermore, $60 \%$ of respondents learning models. Relating to this, the su- said that the supervision was done in a pervisors admit that they have not known sudden notification or even without an iniwhat kind of competencies that should be tial notification. Moreover, $60 \%$ of responowned by teachers of cultural arts. This dents argued that the supervisors seemed causes more difficulties for the cultural art to only find the fault of teachers during teachers to really understand of what kind the supervision. In addition to this, $80 \%$ of of competencies needed by their students respondents said that the supervisor never in order to produce potentially prepared graduates.

In the evaluation stage, the supervisor evaluates what has been planned and done before. He writes an administrative report on supervision that has been done le. on the teachers.

The supervisory model as described before, shows that the current supervision has not met the concepts and principles of the ideal supervision because of its poor planning. It is said so since the supervision is realized on the initiative of the supervisor based on the monthly program. Moreover, the supervision implementation is conducted administratively only, by checking several teaching documents, so that the instrument used is only limited to the lesson planning instrument. In addition to this is the use of a general instrument. It means that the instrument used in the supervision has not reflected the true characteristics of the cultural art subject. Meanwhile, the supervision evaluation is only given in a form of supervision activity report. Supervision which has been cardistributed questionnaires to collect data and information from both teachers and students. Finally, as many as $60 \%$ of respondents argued that the supervision was not conducted continuosly and sustainab-

Results of a preliminary study on the implementation of the current academic supervision has several disadvantages they are compared to the ideal condition of an academic supervision, as follows:

1. Supervision tends to be administrative, so that the instrument used is only the lesson planning instrument.

2. Supervision is done based on the program created by the supervisor, while it supposed to be done based on the initiative of the teachers.

3. Supervision is not carried out according to schedule, as a result, teacher missed theopportunity to have the classroom visitation supervision.

4. Not all teachers are supervised, while all teachers supposed to have the equal opportunity to be supervised, as a result, some teachers do not receive the 
benefit of supervision.

5. There are still negative attitudes shown by most of old -more experienced- teachers, whereas, in the ideal condition both supervisor and the teachers should work together to create a harmonious relationship in doing supervision, as a result, difficulties faced by teachers are not identified.

6. Supervision has not been done in a continuous, systematic and sustainable way, while ideally supervision should be done systematically and sustained, as a result, the increase in teachers' ability in teaching can not be monitored.

7. The individual supervision is conducted when examining the of learning administrative document, whilst in the ideal condition it should be done in the classroom after seeing the teaching performance of the teachers, as a result, the teachers' ability in teaching can not be known.

8. A total of $80 \%$ of responses expressed that supervisors never distribute ques- tionnaires, while in the ideal condition the questionnaires have to be distributed to collect data from students about the teachers who are supervised.

9. Supervisor rarely examined the conformity between curriculum and the actual needs of learners, whilst in the ideal condition it needs to be routinely evaluated by the supervisor, consequently, the teachers do not have a sufficient understanding related to the professional competence of a cultural art teacher.

Based on the overview and analysis of the current academic implementation, a factual model of supervision can be illustrated, as follows Figure 1.

From the figure above, stages of the current academic supervision are described, as follows:

1. The school superintendent supervises the target school based on their own initiatives (step 1).

2. The supervision is done based on the

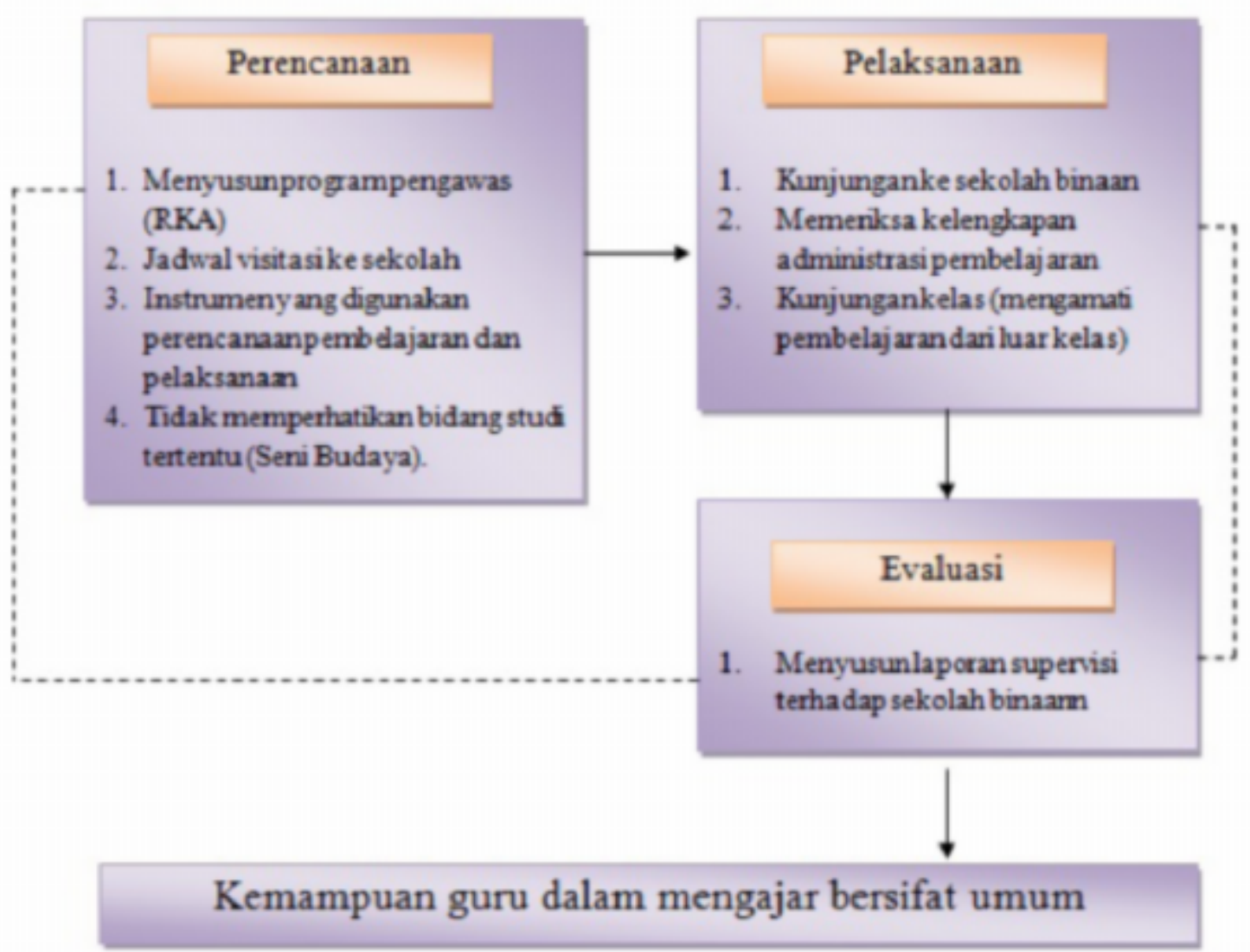

Figure 1. The Factual Model of the Academic Supervision Implementation 
annual program which is created toget- teachers; (2) the results of classroom obher. Based on the annual program, the servation; (3) information from students. semester program is then created, and Later, the supervision is conducted based so does the monthly program. Here, in on the need analysis instrument in a form the monthly program, the supervisor of checklist.

visitation is scheduled.

3. Supervisor visits the target schools. He The Supervision Implementation brings all the administration instru- The implementation stage or suments. pervision implementation comprises vi-

4. The supervisor supervises the teachers sitation to the classroom which involves in target schools and aiming at checking the supervisor, and the teachers who are the completeness of a teacher's admi- supervised. During the class visit, a good nistration document (the syllabus and relationship between the supervisor and lesson plan), and also to identify the the teachers needs to be established, so teacher's competence (step 2).

that teachers will feel guided, welcome,

5. During the process, the supervisor safe and motivated. The attitude of acceptends to use the lesson planning instru- ting and listening to the feelings of others, ment more frequent. It is said so sin- understanding others, so that people can ce the supervisor usually checks the be themselves is actually the developed teaching documents before a teacher attitude in artistic supervision. The classis entering the classroom. The instru- room visit itself is conducted based on the ment related to the implementation need analysis in which the data was gatheand learning assessment is rarely used red from the previous observation.

since the supervisor rarely observed the classroom directly.

6. The classroom is observed from outsi- sion de the class.

The Evaluation and Follow-Up Supervi-

7. The stage of evaluation is conducted through the supervision activity report.

\section{The Conceptual Model Development}

The design model is developed from the empirical model exploration result in the field of the literature review. Overall, a holistic academic supervision model is explained, as follows:

\section{The Supervision Planning}

The supervision program is started by the initial meeting between teachers and the school superintendent. The planning is created based on the teachers' own initiatives. Teachers feel the need of supervision since they face several difficulties during the classroom teaching and learning activity.

In the initial meeting, the school superintendent, and the supervised teachers are identifying the need analysis together on the basis of (1) Information from the

Evaluation is done by discussing and analyzing the results of the implementation of supervision between supervisors and teachers who supervised in order to find solutions to the problems faced by teachers during the teaching and learning process.

\section{The Hypothetic Model Development/ Fi- nal}

The final model is a model that has been validated and tested on a limited scale. Generally, a holistic model-based academic supervision can be explained, as follows:

\section{The Supervision Planning}

The supervision program begins with an initial meeting between teachers and the supervisor. The planning is created based on the initiative of the teacher. Teachers feel the need to be supervised because they find problems in classroom teaching and learning activity. The supervisor and teachers who are supervised cooperate each others in developing the 
supervision timetable and programs.

In the initial meeting, the supervisor and teachers who are supervised identify the need analysis based on: 1) Information from the teachers; 2) the results of classroom observation; and 3) information from learners. Based on the needs analysis, the supervisor and teachers who are supervised started to plan supervision program.

\section{The Implemented Instruments}

In conducting the supervision, the planning instrument, the learning implementation instrument (classroom observation instrument) as well as the classroom visit observation instrument is held by the supervisor. Another instrument which is also used by the supervisor is the learning assessment instrument which will be used in the evaluation stage.

\section{The Implementation of Supervision}

A holistic academic supervision is originated from the awareness of teachers towards their own weaknesses, thus, requiring a supervisor to help in fixing the weaknesses in them. The initial meeting between supervisors and the supervised teachers aims to plan and design a supervision program. The planning is based on a need analysis which is gathered from the observations conducted jointly by the teachers who are supervised and the supervisor. According to Pidarta (2009), the supervision technique of classroom observations should involve a supervisor to observe the teacher for one learning session. It purposes to: 1) determine the overall way of teachers in educating and teaching the students, as well as to recognize the teachers' personality and way of teaching; 2) to perceive the response of learners.

In the stage of supervision implementation, here is a classroom visit which involves both the supervisor and teachers during the visitation. During the classroom visit, a supervisor needs to establish a good relationship with the teachers who are supervised, thus, teachers will feel guided, welcome, safe and motivated. The attitude of accepting and listening to the feelings of others as well as understanding others to make people to be themselves is an attitude that supposes to develop with the artistic supervision.

The classroom visit itself is carried out based on the need analysis in which the data are obtained from the results of previous observations. Classroom visit is undertaken as part of the supervision program in which the plan was created by both a supervisor and the teachers.

\section{Evaluation and Follow-up Supervision}

A holistic academic supervision has evaluation components and follow-up with the aim to assess whether the supervision has been carried out according to plan and the main purpose of supervision. Evaluation is done by discussing and analyzing the results of the implementation of supervision between supervisors and teachers who supervised and to find solutions to the problems faced by teachers in learning.

Based on the agreement between the supervisor and teachers who are supervised, at the stage of follow-up, a classroom observation will be conducted in order to see the teacher's ability in teaching and their mastery towards the characteristic of cultural art teachers.

The following is the list of specific characteristics that distinguish this supervision model with other models of supervision:

a. The supervision initiative comes from both the supervisor and the teachers, thus, a good communication can be established.

b. The supervision is requested by the teachers in order to make a betterment of their weaknesses, whether it is true or false.

c.There is a feedback meeting after the supervision is conducted in order to discuss the results of supervision.

d.A complete series of supervision instruments, comprising the lesson planning as well as the implementation and assessment of learning which has been suitable with the characteristics of cultural arts. 
e.Reinforcement which is intended to encourage teachers to not easily feel hopeless.

f.Follow-up to improve the weaknesses found during the supervision process.

The elements involved as the practitioner of this holistic academic supervision are (1) School Superintendent, (2) Teachers, and (3) Students. These three elements are closely related to each other and mutually supportive.

The school superintendent is assigned by the government through Department of Education to supervise schools under their authorities. The main tasks of a school superintendent (school supervisor) are: 1) to establish an effective communication with the teachers who are supervised and to monitor the implementation of supervision; 2) to carry out an academic supervision by providing a professional assistance to teachers according to the needs or difficulties had by teachers in classroom teaching, in this case is cultural art subject. Meanwhile, the teacher's role is to convey the problems they faced to the supervisor in order to obtain the necessary assistance. And finally, the role of learners are to provide inputs to the supervisor about the teachers who are supervised.

Broadly, the hypothetical model (final model) is illustrated as follows Figure 2.

The following is the implementation procedure of a holistic supervision model:

\section{The Planning Stage}

In this stage, the supervision schedule (starting from the initial planning up to the follow-up) is created and the administrative requirement formats are arranged.

Some of the activities are:

1. The teacher took the initiative to request a supervision

2. After that, the teachers are asked to fill out a supervision plan based on the specific format which has been suited with the cultural art subject.

3. Schools or the teachers provide the learning documentation which has been suited with the rules of the cultural art learning.

4. Coordination is held between the supervisor and the school headmaster during the supervision.

5. The supervisor and teachers who are supervised hold an initial meeting to determine the need analysis and design a plan, including to do the administrative requirement checking by using a planning sheet.

6. The supervisors also requested information from the students about the teachers who are supervised.

7. In addition to the information given by the supervised teacher and the students, the supervisor also conducts a classroom observations (initial observation) to determine the weakness part of the teachers.

8. Both supervisor and the teachers analyze the classroom observation results.

\section{The Implementation Stage:}

The supervisor and the teachers conduct a class visit based on the agreed schedule.

The activities are described as follows:

The supervisor and teachers do the classroom visit supervision to follow up the classroom observation results by following the learning implementation supervision instrument. This activity is performed for about 15 minutes to observe several parts of the learning process. Here, the supervisor is allowed to intervene when the teacher was teaching as long as they hold to the principle of mutual respect.

\section{The Evaluation Stage:}

At this stage, the supervisor is required to assess whether the implementation of a supervision has been conducted as planned.

The activities are described as follows:

In this evaluation stage, the supervisor analyzes the classroom visitation supervision result. On the other hand, the teachers also have the opportunity to give 


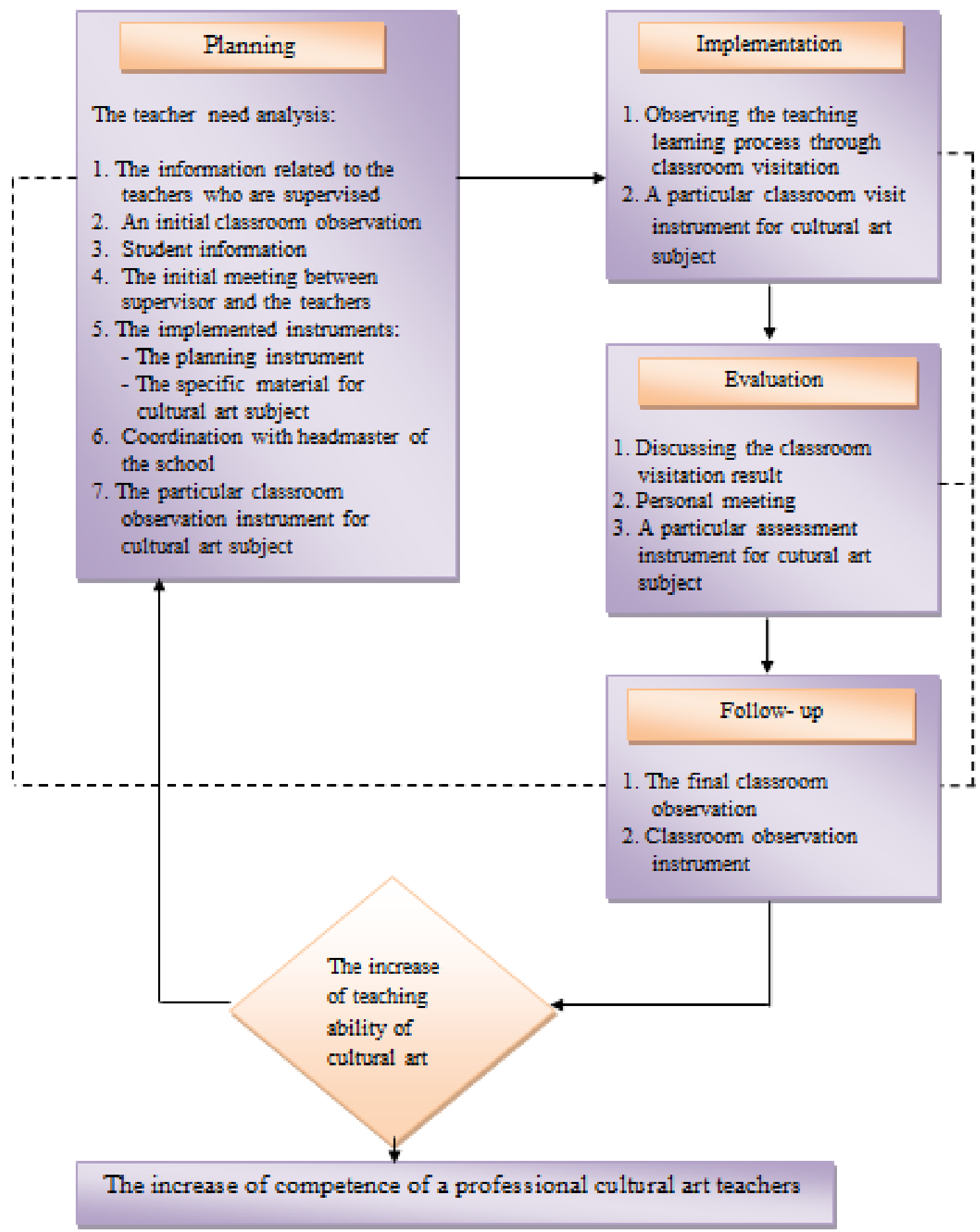

Figure 2. The Final Model of a Holistic Academic Supervision

their evaluation towards the conducted The expert validation towards the supervision. The supervisor is also requi- development results of the supervision red to assess the ability of teachers in using model is carried out by two university exthe learning assessment instruments. perts while the practitioner evaluation is conducted by a supervisor and a principal.

\section{The Model Validation and Focus Group} Discussion Overall, the expert validation as well as the practitioners claim that the design of a 
holistic model of academic supervision be- the maximum one. Thus, in overall calculong to a good category. It means that this lation, a teacher can earn a minimum score supervision model is possible to be done of 20 and a maximum of 100 . The results with a little revision.

\section{Evaluation (The Trials)}

The holistic academic supervision model is tried out in SMK 1 Pringapus (Vocational High School 1 Pringapus), SMK NU Ungaran (Vocational High School NU Ungaran), SMK 1 Tengaran (Vocational High School 1 Tengaran), and SMK Mahesa PSAK Ambarawa (Vocational High School Mahesa PSAK Ambarawa). There are six cultural art teachers take part as the participants in the proposed model trials.

The trial is carried out before (pretest) and after (post-test) the implementation of holistic academic supervision model. Prior to the application of the model, the trial subject is observed in classroom observation by a supervisor in order to see the ability of the trial subject in conducting a classroom teaching. The instrument used is the classroom observation instrument (the learning implementation focuses specifically on the cultural art subject). There are 20 components to be assessed and the scores of each component are arranged starting from 1 as the lowest score up to 5 as of classroom observations prior the implementation of holistic academic supervision model is considered as a pretest. Once the proposed model is applied, the classroom observation will be re-conducted and the results will be considered as the posttest.

The effectiveness of an academic supervision will be achieved if there is an increase in the ability of teachers in implementing the classroom teaching and learning activity, starting from the opening activity, the core, and the closing activity. The activity is arranged into 20 components. From the 20 assessed components, there are components of professional competence of the cultural art teacher. It aims to assess the ability of teachers in directing the lesson to be more contextual, appreciative, creative and expressive. The scores obtained from the classroom observation are converted in percentage and grouped in the category of Excellent, Good, Fair, and Poor.

The pretest and posttest results of observations from six trial subjects on the effectiveness of academic supervision can be seen in Figure 3.

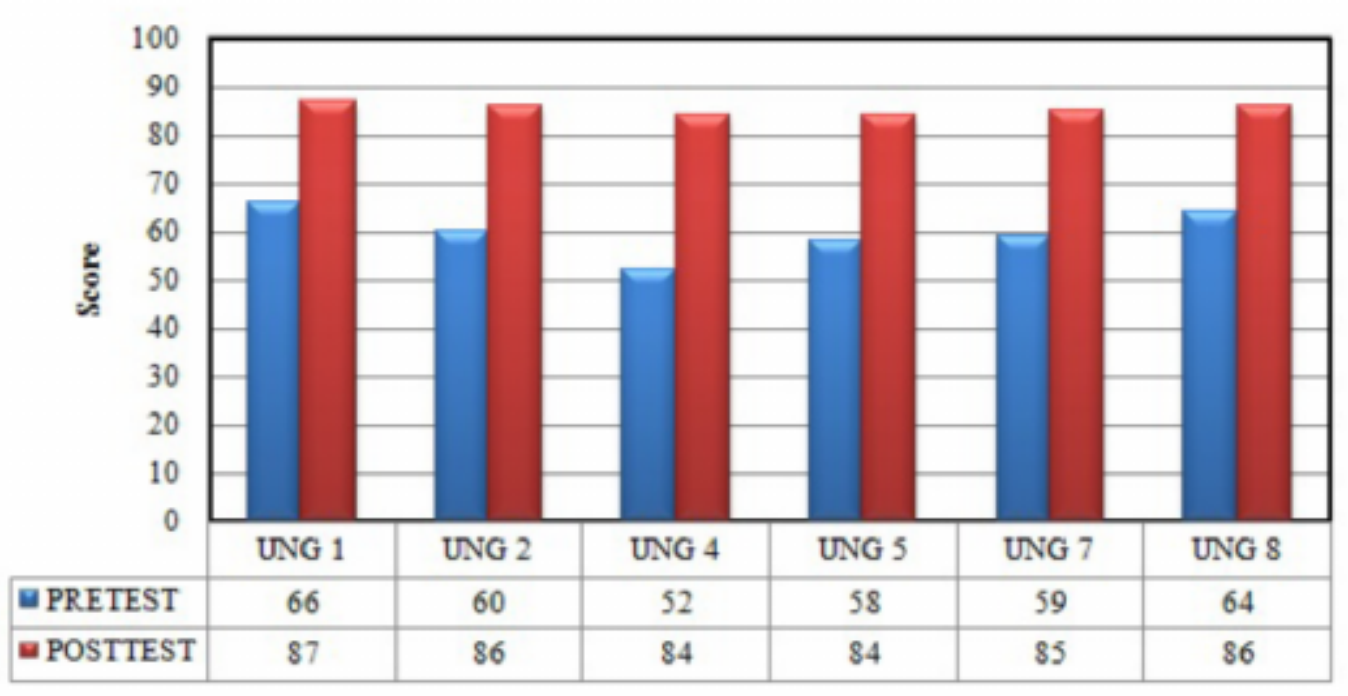

Figure 3. The result comparison of classroom observation pretest and posttest 
The effectiveness level of the propo- a supervision model as proposed in this sed model is determined using the index study is also directed to enhance the progain by comparing the results of the pre- fessional competence had by cultural art test and posttest.

\section{teachers.}

The supervision model developed in

\section{Discussion}

The current implementation of academic supervision at schools is considered less effective. Instruments used are still using the same format for all subjects, although the cultural art subject actually has its own special characteristics. Furthermore, ideally, in order to supervise a cultural art teacher, the supervisor must have the same educational background or at least the same educational field as the teacher who is supervised.

Supervision which is done the school superintendent is also still uneven. There are teachers who are often supervised, on the other hand, there are teachers who are never been supervised. Teachers entitled to the same opportunity to be supervised, as proposed by Mukhtar and Iskandar (2013, p. 58). They argued that all teachers need and are entitled to a supervisor. Supervisors who do not visit schools to help teachers in solving their teaching problems can be categorized as autocratic and authoritarian. It will cause the feeling of unease on teachers, so they will feel resistance in sharing their problems to the supervisor. They do not believe in the concept of supervision as the process of sharing, helping, guiding, counselling and motivating teachers to solve problems they encounter in the classroom while teaching (Behlol, 2011, p. 35) .

The proposed academic supervision model developed in this study is a model of academic supervision which is expected to meet the expectations or needs of vocational high school teachers, especially teachers of the cultural art subject. It is also created to suit the concepts and principles of supervision. The supervision is not expected to be conducted administratively, but rather to a more comprehensive package. It needs to comprise the more characteristic features which reflect the nature of cultural art teachers. The development of this study also aims to improve the effectiveness of supervision. This is in line with Afolakomi, Ordein and David (2007) and Holland and Adams (2000) who state that the supervision is carried out effectively to support professional development and improve the ability of teachers in teaching. The improvement of teachers' teaching abilities has a very strong influence on the achievement of students as reflected in the learning outcomes. Therefore, in order to run an effective supervision, all stages proposed in this holistic-based supervision model should be implemented.

Supervision models developed in this study can be considered as an effective model. The model is initiated by the teacher. It means that teachers are not forced to undergo supervision. It is in line with what has mentioned by Kurniawan (2005, p. 109) that a duty or a function of an organization will be considered effective if it is free from pressure or tension. A similar argument is stated by Handoko (1995, p. 7) that a program is said to be effective if it has the right instruments to achieve its intended purposes. Here, the proposed model in this study has attempted to provide the proper instruments to achieve the expected goals. Later, after implementing the supervision, teachers are expected to receive an appropriate assistance as designed in the initial planning. This means that the supervision model developed in this study is effective. The supervision instruments which have been designed specifically to meet the need of a cultural art teacher will give assurance that the implementation of academic supervision of a cultural art teacher is going to be effective. Even, the detailed aspects as available in the instrument of supervision is possible to be used by all people even when he does not master cultural art as their educational background.

A holistic academic supervision 
model allows classroom visitation which classroom visitation and also the subseenables the supervisor and the supervised quent activities. The private meeting can teachers to collaboratively involved in the be done formally or informally, before or activity. During the classroom visit, the after the classroom visitation (Department supervisor is expected to maintain a good of National Education, 2008). Further, the relationship with the teacher who is super- private meeting also can be done after the vised, thus, the teacher will feel guided, class visit through everyday conversation. welcome, safe and motivated. The attitude It means that the meeting is conducted in in accepting and listening to the feelings of a relax atmosphere as if the supervisor and others as well as understanding others in teachers are co-workers (Sri, 2011).

order to make people to be themselves is

At the stage of supervision followa kind of attitude that is developed in the up, the supervisor and teachers who are artistic supervision. The classroom visit is supervised need to do the learning obsercarried out based on the need analysis in vation. Further, the results are discussed which data is gathered from the previous and concluded whether the ability of teobservation. The classroom visit is under- achers who are supervised is increased or taken as part of the supervision program not. If it is increased, the supervisor needs which is planned by both a supervisor and to appreciate it in order to maintain and the teachers.

Classroom visit is conducted by a school superintendent in order to obtain the data needed by supervisor based on the need analysis. The supervisor needs a data sample since the supervisor wants to dig it deeper. The reason behind this is usually because: (1) based on the results of previous supervision, the teacher has a weakness in it; (2) it is based on the agreement between the supervisor and the supervised teacher on their initial meeting right after the end of the previous supervision; (3) teacher needs improvement on that specific field; and (4) the superintendent receives information that the teacher is weak in certain case (Pidarta, 2009, p. 100).

A good criteria of classroom visit by Department of National Education (2008) are as follows: (1) have a clear objective; (2) reveal aspects that can be used by teachers to improve their teaching ability; (3) using observation sheet; (4) establishing a good the interaction between supervisor and teachers who are supervised; (5) does not disrupt the learning process; and (6) conduct a follow-up activity. With the supervisor visits the class, the needed data can be obtained to improve the teacher's weaknesses.

In the stage of evaluation, the supervisor and teachers who are supervised held a private meeting to discuss the results of

further improved the accomplishment made by the teachers. On the contrary, if there is no improvement, supervisor has to give motivation and make plans for further corrective measures.

\section{CONCLUSION}

From the results of study, conclusions can be generated regarding to: (1) the current supervision model for cultural art teachers of Vocational High School in Semarang Regency; (2) The hypothetical model of holistic -based academic supervision to enhance the professional competence of vocational high school cultural art teachers; (3) The final model of holistic academic supervision which is considered effective to improve the professional competence of vocational high school cultural art teachers.

First. Up to these days, the implementation of academic supervision conducted by vocational high school supervisor in Semarang Regency for the cultural art teachers is still considerably general and has not met the needs of teachers as well as the characteristics of cultural art subject. The relationship between supervisor, headmaster and the teachers is relatively poor. Further, the supervision is still lack for observation or class visitation made by the supervisors or school supe- 
rintendent. The supervision itself has not Ambarwangi, S. (2013) . Pendidikan Mulbeen evenly distributed to all teachers and teacher attitudes are still negative in facing the supervision since supervision is identical with assessment. As a consequence, it has not led to the professional competence Ambarwangi, S. (2014). Reog as Means of improvement of cultural art teachers.

Second. The academic supervision model which is considered appropriate for vocational high school is a holistic model of academic supervision. It is believed that this model will be able to overcome the weaknesses of the current supervision which has been carried out over the years. This model can also give a new point of view regarding to the supervisiom, such as: supervision is not always carried out based on the supervisor's initiative, it is not an inspection, it can help in solving the teachers' problem in teaching, it is not an administrative checking, it may give a professional help for the teachers, it has reflected the cultural art characteristics, it is conducted based on the schedule, and it allows for an agreement regarding to the scope of supervision.

Third. A holistic academic supervision model can improve the effectiveness of academic supervision in terms of classroom observation. It will increase the ability of teachers in carrying out the teaching and learning activities in the classroom. Study on six test subjects was done to prove that there is an increase in the ability of teachers in conducting a classroom teaching with the level of effectiveness belongs to medium category. In addition to this, willlcoxon test has shown that there is an increase in the effectiveness of the supervision.

\section{REFERENCES}

Ali, Muhammad. (2002). Guru dalam Pros- Hasibuan, M. (2003). Manajemen Sumber es Belajar Mengajar. Bandung: Sinar BaruAlgensindo

Afolakemi, O. \& David, O. (2007). Supervision and Quality of Teaching Personnel Effects on Students' Academic Performance. Educational Research and Review Vol. 2 (3). pp. 032-035. tikultural di Sekolah melalui Pendidikan Seni Tradisi. Harmonia Journal of Arts Research and Education, 13 (1), 78-85. Students' Appreciation and Creation in Arts and Culture on The Local Wisdom. Harmonia Journal of Arts Research and Education, 14 (1), 37-45.

Arifah, Neny. (2006). Pengembangan Supervisi Klinis untuk meningkatkan keterampilan dasar mengajar guru. Tesis. Surabaya : Pascasarjana Universitas Surabaya.

Behlol, M. G. (2011). Concept of Supervision and Supervisory Practices at Primary Level in Pakistan. International Education Studies, 4 (4), 28-35.

Borg \& Gall (1989). Educational Research: An Introduction, Fifth Edition. New York: Longman

Burhanudin. (2005). Administrasi Pendidikan. Bandung: Pustaka Setia.

Creswell, J.W. (2003). Research Design: Qualitative, Quantitative, and Mixed Methods Approaches (Second Edition). London: Sage Publications Ltd.

Depdikbud. (2012). Pedoman Penilaian Kinerja Pengawas Sekolah Muda/ Madya/ Utama. Jakarta: Depdikbud P2TK.

Kompas.com. (2012, August 1). PGRI tak Percaya Hasil Tes UKG. Retrieved from Kompas.com http:edukasi.compas.co.Desember 10, 2014.

Glickman, C. D. (1995). Supervision of Instruction. Boston : Allyn and Bacon Inc.

Glickman, C. D., Gordon, J. M. (1995). Supervision of Instruction: A developmental approach (3 $r d$ ed.). Boston: Allyn and Bacon. Daya Manusia. Jakarta: PT. Bumi Aksara.

Jaffer, K. (2010). School Inspection and Supervision in Pakistan: Approaches and Issues. Prospect. 40 (3), 375-392.

Kun, S. A. (2010). Pengembangan Model Evaluasi Pembelajaran Seni Budaya 
SMP. Jurnal Kependidikan, 40 (1) 8798.

Kurniawan, A. (2005). Transformasi Pelayanan Publik.Yogyakarta: Pembaharuan.

Lazaruht, S. (1988). Kepala Sekolah dan Tanggung Jawabnya. Yogyakarta: Kanisius.

Kamaril, Cut. 2001. Konsep Pendidikan Seni Tingkat SD-SLTP-SMU. Paper presented on Seminar dan Lokakarya Nasional Pendidikan Seni on 18-20 April 2001. Jakarta.

Mukhtar \& Iskandar. (2009). Orientasi Baru Supervisi Pendidikan. Jakarta: Gaung

Mulyasa. (2007). Standar Kompetensi Sertifikasi Guru. Bandung : Remaja Rosda karya.

Depdikbud. (2007). Peraturan Menteri Pendidikan Nasional No.12 tahun 2007 tentang Standar Pengawas Sekolah/Madrasah. Jakarta: Badan Standar Nasional Pendidikan.

Depdikbud. (2005). Peraturan Pemerintah No.19 tahun 2005 tentang Standar Pengelolaan. Jakarta: Badan Standar Nasional Pendidikan.

Purwanto, Ngalim. 2003. Administrasi dan supervisi pendidikan. Bandung: PT Remaja: Rosdakarya

Rusman . 2009. Manajemen Kurikulum. Jakarta: Raja grafindo Persada.

Sahertian, Piet A. (2008). Konsep Dasar dan Teknik Supervisi Pendidikan Dalam Rangka Pengembangan Sumber Daya Manusia, Jakarta: Rineka Cipta.

Samsudi. (2009). Desain Penelitian Pendidikan. Semarang : Unnes Press.
Sugiyono. (2010). Metode Penelitian Pendidikan. Bandung: ALFABETA

Soutopo, Hendiyat. (2002). Kepemimmpinan dan Supervisi Pendidikan. Jakarta: Bina Aksara.

Sukidin, B., Suranto. (2008). Manejemen Penelitian Tindakan Kelas. Jakarta: Insan Cendiki.

Sudjana, Nana. (2012). Supervisi Pendidikan Konsep dan Aplikasinya Bagi Pengawas Sekolah. Bekasi : Binamitra Publishing.

Suharto, S. (2011). Pengembangan Materi dan Kegiatan Pembelajarannya dalam Kurikulum Tingkat Satuan Pendidikan Bidang Seni Musik. Harmonia: Journal Of Arts Research And Education, 8(3). doi:http://dx.doi.org/10.15294/har monia.v8i3.780

Suharto, S. (2013). Poblematika Pelaksanaan Pendidikan Seni Musik di Sekolah Kejuruan non Seni. Harmonia: Journal of Arts Research And Education, 12(1). doi:http://dx.doi.org/10.15294/harmoni a.v12i1.2221

Suharto. (2012). Probematika Pelaksanaan Pendidikan Seni Musik di Sekolah Kejuruan Non Seni. Harmonia Journal of Arts Research and Education, 12 (1), 87-94.

Supriyono. (2011). Pengaruh Sistem Supervisi Akademik Pengawas Sekolah Terhadap Profesional Guru SMA Negeri 1 Padang Ratu Lampung Tengah. Thesis. Lampung: Post Graduate Program, UNNES.

Widodo, J. (2007). Supervisi Guru Mata Pelajaran Ekonomi di Indonesia : antara teori dan realita". Jurnal Pendidikan Ekonomi. 2 (2), 291-313.

Zepeda, S.J., \& Ponticell, J. A. (1998). At Cross-Purpose: what do Teacher Need, Want, and get from Supervision? Journal of Curriculum and Supervision, 14 (1), 68-87. 